\title{
Rевевсн Автіск: Preliminary study on germination of pre-treated seed of red sanders under nursery conditions from Tamil Nadu
}

\section{口 K.P. VIJAYALAKSHMI AND P.R. RENGANAYAKI}

Article Chronicle: Received :

11.07.2017;

Accepted :

26.07.2017

KeY Words:

Mechanical clipping, Cow dung slurry,

Speed of germination, Vigour index

Author for correspondence :

\section{K.P. VIJAYALAKSHMI} Forest College and Research Institute Tamil Nadu Agricultural

University,

METTUPALAYAM

(T.N.) INDIA

Email: vijayalakshmikp

12@gmail.com

See end of the article for authors' affiliations
SUMMARY : The field experiment was carried out during 2015-16 at Forest College and Research Institute, Mettupalayam, Tamil Nadu, India to study the effect of pre-treated seed of red sanders under nursery conditions. The results indicated that there was significant effect of Alternate Wetting and Drying (48h) over control. The significantly early ( 8 days) and maximum $(73 \%)$ germination and speed of germination were recorded in treatment having Alternate Wetting and Drying (48h). The seedling height $(19.77 \mathrm{~cm})$, dry weight $(0.24 \mathrm{~g})$ were also higher with treatment Alternate Wetting and Drying (48h).

How to cite this article : Vijayalakshmi, K.P. and Renganayaki, P.R. (2017).Preliminary study on germination of pre-treated seed of red sanders under nursery conditions from Tamil Nadu. Agric. Update, 12 (TECHSEAR-4): 956-959; DOI: 10.15740/HAS/AU/12.TECHSEAR (4)2017/956-959. 